\title{
A Case of Idiopathic Spontaneous Tonsillar Hemorrhage
}

\author{
Jong Eui Hong, Jae Hyung Hong, Sang Yul Shim and Chan Kee Yoo \\ Department of Otolaryngology-Head and Neck Surgery, CHA Bundang Medical Center, CHA University, Seongnam, Korea
}

\section{특발성 자발성 편도 출혈 1 예}

홍종의 · 홍재형 · 심상열 · 유찬기

차의과학대학교 분당차병원 이비인후과학교실

\author{
Received November 5, 2010 \\ Revised December 1, 2010 \\ Accepted December 29, 2010 \\ Address for correspondence \\ Chan Kee Yoo, MD, PhD \\ Department of Otolaryngology- \\ Head and Neck Surgery, \\ CHA Bundang Medical Center, \\ CHA University, \\ 351 Yatap-dong, Bundang-gu, \\ Seongnam 463-712, Korea \\ Tel $+82-31-780-5340$ \\ Fax $+82-31-780-5347$ \\ E-mail yoochankee@empal.com
}

Spontaneous tonsillar hemorrhage (STH) is an extremely rare event. Usually, the causes of STH are ascribed to vessel wall erosion secondary to bacterial or viral infection of tonsils. Other causes include vascular or tumorous lesions around tonsil, coagulation disorders and idiopathic one. On one hand, the total number of reported STH has slightly increased because STH is defined as all forms of "bleeding tonsils", including even minor bleeding. On the other hand, the portion of the total STH that is life-threatening has become relatively few. Management of STH involves the use of antibiotics, and early tonsillectomy is recommended. We have experienced a case of a 29 year-old female with tonsillar hemorrhage in the absence of any identifiable cause. We report the case with a review of the related literatures.

Korean J Otorhinolaryngol-Head Neck Surg 2011;54:344-6
서 론

자발성 편도 출혈은 매우 드문 현상으로 대부분 편도염 이후에 발생한다. ${ }^{1-6)}$ 또한 출혈성 질환, 종양성 질환, 혈관성 질환도 원인이 될 수 있으며, 이전의 몇몇 논문에서 편도주 위농양, 측인두공간 또는 인두후공간 감염 후, 그리고 드물게 혈관 기형, 경동맥이나 천측두동맥의 동맥류 또는 가성동맥 류를 원인으로 보고하였으며 ${ }^{1,2)}$ 특발성 출혈도 보고된 바 있다. ${ }^{3}$

대부분의 보고된 문헌에서는 편도에서 일어난 모든 출혈 로 정의하였기에 빈도가 과거보다 증가하였지만, 보고된 문 헌 중 생명을 위협하는 과출혈이 일어난 증례는 상대적으로 줄게 되었다. ${ }^{4,5}$ 하지만 원인과 상관없이 대부분의 자발성 편 도 출혈은 항생제 사용 및 조기 편도절제술을 통해 치료하는 것이 일반적인 치료법이다. ${ }^{3,4)}$

저자들은 특별한 원인을 발견하지 못한 자발성 편도 출혈 환자를 경험하였기에 문헌고찰을 통해 자발성 편도 출혈의 임상적 특성을 알아보기 위해 본 증례를 보고하는 바이다.
증 례

29 세 여자 환자가 내원 4 시간 전 발생한 구강출혈을 주소 로 응급실 내원하였다. 선홍빛의 출혈이었으며 종이컵 2 컵 이상 분량으로 약 $300 \mathrm{~mL}$ 정도로 추정되었다. 환자가 응급 실에 내원한 직후 짧은 시간 동안 한 차례 더 종이컵 2 컵 분 량의 출혈이 있었다. 환자는 전날 가벼운 술자리로 몇번의 기 침 이외에는 외상을 받은 적이 없다고 하였으며, 주소와 관련 하여 인후통이나 연하곤란, 기침, 가래 등의 상기도 감염 증 상은 호소하지 않았고 전신상태 또한 양호하였다. 환자는 13 년 전 폐결핵 완치판정을 받았으며 그 외 다른 병력이나 가 족력 등은 없었다. 출혈 소인을 의심할만한 병력이나 가족력 또한 없었다. 환자는 10 갑년(pack year)의 흡연자였으며 소 주 1 병 정도의 주 1,2 회 음주력이 있었다. 급성 편도염을 자주 않았다고 하였으며, 내원 두 달 전 급성 편도염으로 치료받 은 과거력이 있었다.

신체 검사상 체온은 정상이었으며 다른 생체징후도 안정 적이었고 경부임파선 종대는 없었다. 구강 및 인후두 검사 
상, 편도 비대 정도는 Brodsky scale 상ㄱ 각각 1+였으며, 우측 편도의 상극에서 혈괴가 관찰되었고(Fig. $1 \mathrm{~A}$ ) 흡인기 로 혈괴를 제거하자 삼출성 출혈(oozing bleeding)이 발생 하여 에피네프린(epinephrine)을 묻힌 거즈로 압박하여 지 혈하였다. 그 외 편도 및 구강 점막에 발적, 부종 등의 염증 성 변화는 없었으며, 종양성 혹은 혈관성 병변을 의심할만한 소견은 관찰되지 않았다(Fig. 1B).

응급실에서 시행한 실험실 검사상 백혈구 $5,280 / \mathrm{uL}(\mathrm{seg}$ $34 \%)$, 혈색소 $12.3 \mathrm{~g} / \mathrm{dL}$, 혈소판 $270,000 / \mathrm{uL}$ 로 정상이었 으며 혈색소 수치는 다음 날 $10.9 \mathrm{~g} / \mathrm{dL}$ 로 감소하였다. 혈액 응고검사 상 프로트롬빈시간(prothrombin time, PT)은 11.5 초(105\%, INR 1.00), 활성화 부분 트롬보플라스틴 시 간(activated partial thromboplastin time, aPTT)은 38.7초로 모두 정상범위였다. 엡스타인-바 바이러스(Epstein-Barr virus, EBV) 관련 검사는 음성이었으며 말초 혈액도말검사상 비정형세포는 관찰되지 않았다.

환자에게 경부전산화단층촬영을 시행하였으며 특이 소견 은 관찰되지 않았다(Fig. 2). 폐결핵 병력이 있었기 때문에 흥부전산화단층촬영 및 기관지내시경검사를 시행하였으나 출혈이나 결핵의 재발을 의심케 하는 소견은 관찰되지 않았 고 상부위장관 내시경 검사에서도 출혈의 증거는 없었다.

입원 3 일 후, 더 이상의 출혈 소견은 보이지 않고 신체 검 사상 특이 소견 없어 퇴원하였다. 현재까지 약 2 년 동안 재발
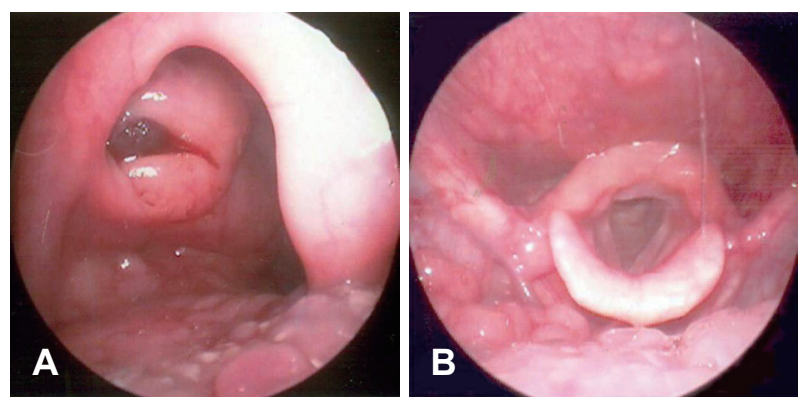

Fig. 1. Blood clot was noted at the upper pole of the right tonsil (A). There were no bleeding focuses or traces around the larynx (B).

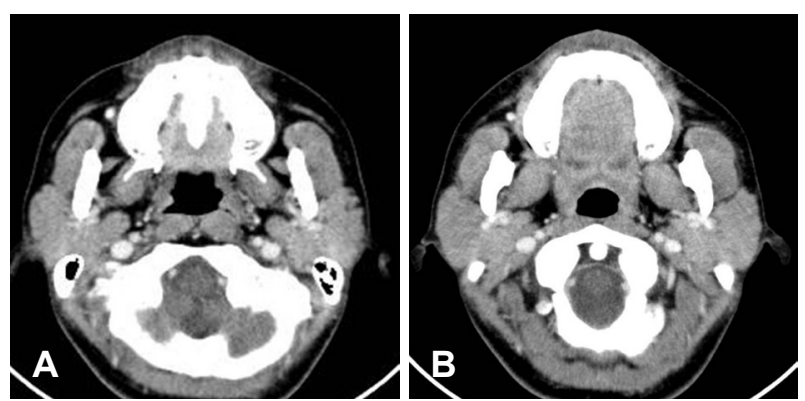

Fig. 2. There were no tumorous or vascular lesions from upper pole of both tonsil $(A)$ to lower pole of both tonsils $(B)$ on contrast enhanced CT.
없었으며, 더 이상 편도염을 않지 않았다고 하여 아직 편도 절제술은 시행하지 않은 상태로 외래 추적관찰 중이다.

\section{고 찰}

자발성 편도 출혈은 매우 드물게 발생하는 현상으로, 이전 의 논문에서도 보고된 바가 흔치 않다. Griffies 등는 자발 성 편도 출혈이 한시간 이상 지속되며 시간당 $250 \mathrm{~mL}$ 이상 의 출혈로 정의하여 보고된 860 명의 환자 중 약 10 명만을 그 기준에 부합시켰다면, Watson 등흔 편도에서 발생한 모 든 출혈로 정의하여 많은 증례를 보고하였다. 다행히 자발성 편도 출혈 중 생명을 위협할 정도의 심각한 증례는 극히 드 물다. 본 환자는 시간간격을 두고 총 두 차례 출혈이 진행되 었으며, 응급실 내원 후 약 30 분 사이에 $200 \mathrm{~mL}$ 이상의 경 구출혈을 보였던 점에서 Griffies의 기준에 부합하는 흔치 않은 자발성 편도 출혈의 예였다.

문헌에 보고된 증례들을 살펴보면 편도의 급성 감염성 질 환과 동반하여 발생한 경우가 가장 많다. ${ }^{1-6)}$ 홍역이나 감염 성 단핵구증 등의 바이러스 감염과 세균성 편도염이 자발성 편도 출혈 대부분의 원인이며 이런 경우 병태생리는 급성 염증이 편도의 혈류량을 증가시키고 이차적으로 발생하는 부 종 및 혈관의 울혈로 인해 혈관벽의 미란 혹은 괴사로 출혈 이 야기된다는 것이다. ${ }^{13,5)}$ 또한 자발성 편도 출혈 환자 8 명 중 6 명에서 출혈 이전에 잦은 편도염의 병력이 있어, 만성 편 도염도 자발성 편도 출혈의 선행요인으로 보고하여 급성 염 증뿐 아니라 만성 염증 또한 출혈의 병태생리에 한 부분을 이룰 것으로 추정하기도 한다. ${ }^{4)}$ 그 외 드물지만 편도결석, ${ }^{5}$ 혈관기형, 동맥류와 같은 혈관성 질환, 혈액응고 장애로 인 한 출혈이 보고된 바 있으며, ${ }^{1,2,5,8)}$ 원인을 알 수 없는 특발성 인 경우도 있다. ${ }^{3)}$ 악성종양이 원인으로 보고된 증례가 있었는 데, ${ }^{24)}$ 편도암의 증상으로 구강출혈이 나타날 수 있음을 감안 하면 악성종양에 이차적으로 발생한 편도 출혈의 빈도는 보 고된 경우보다 더 많을 것으로 추정된다. 본 증례의 환자는 조직병리학적 검사를 시행하지는 않았으나 문진, 신체검사, 혈액검사, 영상의학적 검사 및 각종 내시경 검사상 특별한 원 인을 찾지 못하여 특발성 자발성 편도 출혈로 판단하였다.

자발성 편도 출혈은 20 30대에 많이 발생한다는 연구가 있으나 ${ }^{1}$ 문헌들에 따르면 최저 생후 18 개월에 발생한 경우 도 있으며 10 세 전후의 소아에서도 보고된 경우들이 있다. ${ }^{3,6)}$ 남녀비의 차이는 없다는 논문과 ${ }^{1)} 16: 3$ 으로 남자에서 더 흔하다는 논문이 있는데 후자는 연구 대상 병원 중에 2 곳의 군인병원이 들어가 있어 편견(bias)이 발생했을 것으로 생각 된다. ${ }^{5)}$ 일본에서 시행한 연구에서는 약 11 명의 환자를 대상 
으로 남녀 비는 $6: 5$ 였으며, 평균 나이는 29.6세였다. ${ }^{9}$ 양측 편도에서 모두 발생하는 경우는 드물며 편도의 상극(upper pole)에서 많이 발생하는 것으로 보고된 바 있다. ${ }^{1)}$ 또한 계 절적 차이는 없는 것으로 알려져 있다. ${ }^{5)}$

자발성 편도 출혈의 진단을 위해 경구 출혈의 원인이 될 수 있는 모든 감별진단을 해야 한다. 각혈, 객혈, 혈변, 비출 혈을 감별하기 위해 ${ }^{10)}$ 위식도 및 대장 내시경, 세포검사와 결 핵균 확인을 위한 기관지 세정, 그 외 후비공 주위를 포함한 무증상 원발부위가 될 수 있는 공간에서의 조직생검도 시행 해볼 수 있다고 하나, 대부분의 환자에서 자발성 편도 출혈 이외의 다른 문제점이 발견되지 않는다는 점에서 과도한 처 치에 대한 회의적인 입장도 있다. ${ }^{5}$ 혈액검사를 시행하여 출 혈량을 가늠하고, 백혈구 성분 분석을 통해 바이러스나 세 균 감염을 추론해볼 수 있으며, 엡스타인-바 바이러스 감 염 여부를 진단할 수 있다. ${ }^{5}$

출혈의 원인 혈관도 항생제가 발달하기 이전에는 심경부 감염의 대혈관 침범에 의한 자발성 편도 출혈이 빈번히 보 고 되었으나, 항생제의 발달 이후 현재는 말초혈관 출혈이 대부분이어서 그 빈도수도 낮아졌으며 출혈이 경미하여 치 명적인 결과를 야기하는 경우는 드물다. ${ }^{12)}$ 대부분 정맥으로 부터의 출혈이지만 동맥으로부터의 출혈도 보고된 바 있으 며 동맥 출혈일 때는 생체 징후가 흔들리는 응급상황이 올 수 있으므로 즉각적인 대처가 필요하며, 대혈관으로부터의 출 혈이 의심되거나 말초혈관 출혈이 확실치 않은 경우 동맥조영 술의 적응증이 된다. ${ }^{4)}$ Griffies 등)이 발표한 10 명의 심각한 자발성 편도 출혈예 중 7 명은 명백한 정맥 출혈로 관찰되었고 3 명은 심각한 동맥 출혈로 동맥조영술을 시행하였다고 한다.

치료법으로는 대량출혈일 경우 기도를 확보하고 저혈량성 쇼크와 흡인에 대비한 응급처치를 시행하여야 한다. 대부분 의 경우에서처럼 출혈이 경미할 때는 급성감염이 동반된 경 우 항생제를 사용하며 경과 관찰하는 방법이 있고, ${ }^{5,6)}$ 화학적 소작술, 전기소작술, 에피네프린 분무 혹은 국소주사 등의 국소 지혈법이 있으며,5,6) 봉합 결찰로 지혈한 경우도 보고되 었다.) 잦은 편도염으로 인한 출혈시 국소요법을 주 치료로 하고, 실제로 편도절제술의 적응증이 되는 경우는 거의 없다 는 주장도 있으나, ${ }^{1,5)}$ 대부분의 문헌에서는 가장 확실한 치 료로 편도절제술을 권유하였다. ${ }^{4.5)}$ 특히 국소지혈법에도 출혈 이 지속되거나, 생명을 위협하는 다량의 출혈 시에는 비록 일
측에서 일어나 출혈일지라도 즉시 양측 편도절제술을 권하였 다. ${ }^{2,5)}$ 이는 편도염 재발로 인해 대측에도 발생할 가능성이 있 기 때문이다. ${ }^{5}$

예방적 편도절제술에 대해서는 아직 이견이 있다. 편도염 에서 자발성 편도 출혈의 발생률은 통계적으로 약 $1.1 \%$ 로, 만성 편도염의 기왕력이 있는 환자는 자발성 편도 출혈의 위 험에 노출되어 있기에 ${ }^{4}$ 한 번 이상 자발성 편도 출혈을 겪었 을 경우 예방적 목적으로 편도절제술을 권하는 논문도 있었 으나, ${ }^{3-6)}$ 국소요법을 통해 지혈이 가능하며, 40 세 이상이거 나, 박동성 종괴가 보일 시 또는 편도 궤양이 있는 경우에는 외래진료를 통한 관찰을 권유하기도 하였다. ${ }^{10)}$ 그 외 이전의 증례와 논문에 의거하여 출혈이 반복되는 경우, 편도염이 자 주 재발하는 경우, 편도암을 의심케하는 임상적 양상이 있는 경우에는 편도절제술이 필요할 것으로 사료된다.

자발성 편도 출혈은 매우 드물어 이전의 논문에서도 보고 된 바가 흔치 않다. 대부분의 편도 출혈 예들이 염증으로 인 한 소량의 출혈인 점에 반해 본 증례는 내원 당시 편도염으 로 의심할만한 증세 및 신체검사 소견이 보이지 않았던 경우 로, 특별한 감염소견 없이 발생한 대량의 편도 출혈로 매우 드문 경우라 문헌고찰과 함께 보고한다.

\section{REFERENCES}

1) Rocha SC, Dell'Aringa AR, Nardi JC, Kobari K, de Melo C. Spontaneus tonsillar hemorrhage. Braz J Otorhinolaryngol 2007;73(2): 287.

2) Vaughan MM, Parker AJ. Idiopathic spontaneous tonsillar hemorrhage. J Laryngol Otol 1993;107(1):44-5.

3) Kumra V, Vastola AP, Keiserman S, Lucente FE. Spontaneous tonsillar hemorrhage. Otolaryngol Head Neck Surg 2001;124(1):51-2.

4) Jawad J, Blayney AW. Spontaneous tonsillar hemorrhage in acute tonsillitis. J Laryngol Otol 1994;108(9):791-4.

5) Griffies WS, Wotowic PW, Wildes TO. Spontaneous tonsillar hemorrhage. Laryngoscope 1988;98(4):365-8.

6) Dawlatly EE, Satti MB, Bohliga LA. Spontaneous tonsillar hemorrhage: an underdiagnosed condition. J Otolaryngol 1998;27(5): 270-4.

7) Brodsky L. Modern assessment of tonsils and adenoids. Pediatr Clin North Am 1989;36(6):1551-69.

8) Jarvis SJ, Parker AJ. External carotid artery aneurysm in an infant presenting with oropharyngeal hemorrhage. J Laryngol Otol 2001; 115(6):500-1.

9) Seuno K, Yamada Y, Suzuki Shin, Yamaguchi T, Yamaguchi S, Nomura Y. Spontaneous tonsillar hemorrhage [in Japanese]. Practica Otologica 2003;96(5):427-34.

10) Salem A, Healy S, Pau H. Management of spontaneous tonsillar bleeding: review. J Laryngol Otol 2010;124(5):470-3. 